\title{
Depth of tillage and its effect on field watershed size in Ejigbo zone, Osun State, Nigeria.
}

\author{
Wasiu Agunbiade Lamidi ${ }^{1,2}$, Adedamola Emmanuel Olawumi ${ }^{2}$, Tunde Amos Oyeranmi \\ ${ }^{1}$ Department of Agricultural Engineering, Faculty of Engineering, College of Science, Engineering and Technology, \\ Osun State University, Osogbo, Nigeria \\ ${ }^{2}$ Department of Agronomy, Faculty of Agricultural Production and Management, College of Agriculture, Ejigbo \\ Campus, Osun State University, Osogbo, Nigeria \\ *Correspondence Email- wasiu.agunbiade@uniosun.edu.ng \\ DOI: $10.4314 /$ rjeste.v4i1.13 \\ https://dx.doi.org/10.4314/rjeste.v4i1.13
}

\begin{abstract}
The study investigated effects of different depths of tillage on flow of runoff in watersheds on fields tilled and planted with maize (Zea mays) hybrids and open pollinated variety (OPV) of maize. Twelve $1 \mathrm{~m} \times 1 \mathrm{~m} \times 2 \mathrm{~m}$ pits were dug and overlaid at all sides and at its bottom with impermeable membrane to accumulate watershed's runoff from the fields. Twelve compartmental plots of $400 \mathrm{~m}^{2}$ each comprising 2 depths of tillage $(0-15 \mathrm{~cm}$ and $0-30 \mathrm{~cm})$ and 2 varieties of maize (hybrids and open pollinated) were used. Each of the treatments was replicated thrice to make $2 \times$ $2 \times 3$ factorial design. Each plot measured $4 \mathrm{~m} \times 10 \mathrm{~m}$ at $2 \mathrm{~m}$ apart. Among the data collected were the volume of water accumulated in the small earthen pits dug, flow velocity $(\mathrm{v} \mathrm{m} / \mathrm{s})$ of water in runoff channels/collectors that fed earthen pits, slopes of the collectors, cross-sectional area of collectors and wetted perimeter. Results revealed that average infiltrometer values of $15.00 \pm 0.24$ $\mathrm{mm} / \mathrm{h}$ and $16.50 \pm 0.40 \mathrm{~mm} / \mathrm{h}$ respectively in the upper part and the lower part were recorded. The 0-15 cm depth of tillage accumulated more volume of runoff water than the 0-30 cm depth of tillage in the pits and it was $23.33 \%$ higher in the lower depth of tillage used on the field than the 0-30 cm depth of tillage. Implying that 0-30 cm tillage depth retained more water from the rainfall compare to the water retained by the $0-15 \mathrm{~cm}$ depth. Even though, volume of runoff water of $0-15$ $\mathrm{cm}$ depth of tillage was higher than that of the $0-30 \mathrm{~cm}$ depth of tillage, $0-15 \mathrm{~cm}$ depth of tillage had the highest yield of maize $\left(9.30 \pm 4.26 \mathrm{t} \mathrm{ha}^{-1}\right)$.
\end{abstract}

Keywords: flow velocity, power tiller, vegetated waterways, wetted perimeter 
Rwanda Journal of Engineering, Science, Technology and Environment, Volume 4, Issue 1, June 2021

eISSN: 2617-233X | print ISSN: 2617-2321

\section{Introduction}

Tillage has been recognized as a factor that causes degradation of natural resources through soil erosion, contamination, deforestation, desertification, salinization and greenhouse gas emissions (Viennet et al., 2019). Tillage enhances soil fertility through reducing soil erosion and ultimately improving crop yields (Pittelkow et al., 2015). Several types of tillage such as minimum tillage, incomplete tillage, reduced tillage, and no till are practiced across the globe (Pagliari et al., 2021). Small resource poor farmers who have adopted conservation tillage methods cite the reduction in labour inputs and drudgery as major drivers for the adoption (Anderson \& D'Souza, 2014).

Tillage depth has a great effect on germination date of maize either when planted in the shallowest sowing depth of $2 \mathrm{~cm}$ or in the deepest sowing depth of $10 \mathrm{~cm}$, (Ghaderi-far et al., 2010; Molatudi \& Mariga, 2009). Some other sown seeds accomplished their germination earlier than others. These are so because the main requirements for germination are air, water and heat; the seed placed near the soil surface accomplishes their germination earlier than deepest one because it is possible that they could receive all the necessary conditions suitable for germination earlier than other seeds planted as deep as up to $10 \mathrm{~cm}$ in the soils (Kim et al., 2020; Brady \& Well, 2002).

Watershed is a geographic area of land that drains all the streams, rills, or channels from where rain falls to common outlets such as the outflow of a reservoir, or mouth of a bay or any point along a stream channel. A watershed may cover all the farm/field or may not, the former was considered in this study. It is of note to know that all bodies of runoff water have a watershed, it may be small or big (Clausen et al., 1996). When it is big, then it may comprise streams, rivers, lakes, reservoirs e.t.c. thus, watershed is everywhere and is very complex. It is of note that anything happening in a watershed affect its water quality (Uttah State University Extension, 2018). Size of watershed is also called drainage basin or drainage catchment.

Watershed land had ability to support the use of various adopted agro-system management practices to reduce their erosivity indices, manages the environmental drainage catchment to provide more water for agriculture, reduces desertification, protects biotic and abiotic lives and to naturally restore the ecosystem (Lamidi, 2014). Besides, ecological benefit is capable of utilising the natural local resources for improving agriculture and allied occupation and industries (small or 
Rwanda Journal of Engineering, Science, Technology and Environment, Volume 4, Issue 1, June 2021

eISSN: 2617-233X | print ISSN: 2617-2321

cottage) such as to improve socio-economic conditions of the local people. With this it is therefore necessary to investigate effect of different depths of tillage on rate of water runoff in watershed on tilled field in Ejigbo Agricultural Zone of Osun State when planted with maize (Zea mays) hybrids and open pollinated maize varieties.

\section{Materials and Methods}

The field experiment was conducted at the teaching and research farm of the College of Agriculture, Osun State University, ( $\left.7^{0} 52^{\prime} \mathrm{N} ; 4^{0} 18^{\prime} \mathrm{E}\right)$ Ejigbo campus in Ejigbo Local Government Area (LGA) of Osun State in 2020. Ejigbo Local Government Area is within Ejigbo zone in Osun State The climate is rain forest with two peaks of rain, the temperature is usually high all year round with mean of $28^{\circ} \mathrm{C}-33^{\circ} \mathrm{C}$, relative humidity of about $75-85 \%$. Tractorisation and desired soil depths for tillage over $0-15 \mathrm{~cm}$ or over $0-30 \mathrm{~cm}$ in different cases for experimental design were ensured not to happen in the field. The dimension of the land was $73 \mathrm{~m} \times 100 \mathrm{~m}$. The land was divided into twelve compartmental plots of $400 \mathrm{~m}^{2}$ each comprising 2 depths of tillage $(0-15 \mathrm{~cm}$ and $0-30 \mathrm{~cm}$ ) and 2 varieties of maize (hybrids and open pollinated varieties, OPV). The whole farm was considered as 12 different compartments. The treatments were laid out in randomized complete block design and replicated three times. Each plot measured $4 \mathrm{~m} \times 10 \mathrm{~m}$ at $2 \mathrm{~m}$ apart from each other. There were ploughing as first phase and ploughing with harrowing as second phase. At both stages, the ploughing and harrowing depths were within either the $0-15 \mathrm{~cm}$ or $0-30$ $\mathrm{cm}$ tillage depths. Power tiller was used because it was easy to control its speed of tractorisation, and to maintain the depths required according to the experimental procedures. The power tiller was made to maintain uniform speed of $5 \mathrm{~km} / \mathrm{h}$ throughout.

Twelve $1 \mathrm{~m} \times 1 \mathrm{~m} \times 2 \mathrm{~m}$ pits were dug and overlaid at all sides and bottom with impermeable membrane. The dug holes were at the final end of each of the 12 final collectors, holes were made up of concrete to accumulate watershed's runoffs from the fields. The pits were graduated for ease of reading and calculations. The essence of impermeable membrane was to disallow percolation of accumulated water during the rainfall and after. Among the data collected were the volume of water accumulated in the small earthen pits dug, flow velocity of water in the runoff collectors/channels that feed earthen pits, slopes of the collectors, cross-sectional area of the collectors and wetted perimeter. The shape of each of the collectors was a trapezoidal with 
roughness coefficient (n) of 2.1 (as it is a non-vegetated waterway) and hydraulic radius was computed (Pagliari et al., 2021; Schwab et al., 1981). There were networks of constructed water collectors like herringbone form that drain water into main channel that led to each pit (Owen, 2006). The collectors were of base, $15 \mathrm{~cm}$; depths $20 \mathrm{~cm}$ and $22 \mathrm{~cm}$ respectively for upper and lower parts of the collectors.

Manning constant, $n=2.1$. This was used in the computation because it is non-vegetated waterway (Lamidi, 2014; Schwab et al., 1981). The research chose the same depth of flow, same wetted perimeter and hydraulic radius for the watershed runoffs' ways throughout the length of the channel for all the collectors. This was to remove error that may be due to discrepancies in the channel design parameters. The research also assumed that velocity calculated is the mean velocity of the moving water in the channel and is usually greater than the velocity of water in contact with the soil.

Trapezoidal channels were used for all the runoff collectors/channels to the constructed accumulating dug pits.

where

$$
\begin{aligned}
& \mathrm{d}=\text { depth of flow; } \\
& \mathrm{b}=\text { bottom width; } \\
& \mathrm{z}=\text { slope of the channel; } \\
& \mathrm{t}=\text { flow top width. }
\end{aligned}
$$

Then

$$
\begin{aligned}
& \mathrm{b}=0.15 \mathrm{~m} ; \mathrm{d}=0.20 \mathrm{~m} ; \mathrm{z}=80 \%=0.8 \text { in the upper parts } \\
& \mathrm{b}=0.15 \mathrm{~m} ; \mathrm{d}=0.22 \mathrm{~m} ; \mathrm{z}=78 \%=0.78 \text { in the lower parts leading to the pit. }
\end{aligned}
$$

In this research, flow velocity was calculated using Manning's formular, 
For open channel flow velocity v,

$$
\mathrm{v}=\frac{R^{2 / 3} \times S^{1 / 2}}{n}
$$

$\mathrm{v}=$ flow velocity,

$\mathrm{R}=\frac{a}{p}$

where

$\mathrm{a}=$ cross-sectional area and

$\mathrm{p}=$ wetted perimeter $(\mathrm{m})$,

$\mathrm{S}=$ slope of channel $(\mathrm{m} / \mathrm{m})$

$\mathrm{n}=$ roughness coefficient ( 0.04 is used for vegetated waterways);

$\mathrm{n}=$ roughness coefficient (2.1 is used for non-vegetated waterways). (Schwab et al., 1981)

\subsection{Statistical Analysis}

The data obtained regarding the flow velocities and crop yields in $\mathrm{kg}$ were subjected to descriptive statistics. Other data collected were subjected to analysis of variance, the means were separated using Duncan Multiple Range Test at 5\% level of significance.

\section{Results}

Table 1 shows the physical and chemical properties of both fields, the soil is sandy loam in both fields. Runoff water and water capacity of these soils were definitely affected by these nature of soils. The soils were different from each other as their values depict, in both cases, the properties show that they are not completely capable of supporting any plant. But the water collectors, dug 
pits for runoff collection, calculations of the collected water as used in the experiment were in order.

Table 1: Physical and chemical properties of the soil in both fields

\begin{tabular}{lll}
\hline Parameters & $\begin{array}{l}\text { Values for hybrid } \\
\text { maize field }\end{array}$ & $\begin{array}{l}\text { Values for open pollinated } \\
\text { maize field, OPV }\end{array}$ \\
Chemical Properties & & \\
$\mathrm{pH}\left(\mathrm{H}_{2} \mathrm{O}\right)$ & 6.40 & 6.44 \\
Organic carbon $(\%)$ & 0.52 & 0.51 \\
Total N $(\mathrm{ppm})$ & 0.041 & 0.04 \\
$\mathrm{Available} \mathrm{P}(\mathrm{mg} / \mathrm{kg})_{\mathrm{Na}^{+}(\mathrm{Cmol} / \mathrm{kg})}$ & 1.07 & 1.081 \\
$\mathrm{~K}^{+}(\mathrm{Cmol} / \mathrm{kg})$ & 0.18 & 0.2 \\
$\mathrm{Ca}^{2+}(\mathrm{Cmol} / \mathrm{kg})$ & 1.22 & 1.26 \\
$\mathrm{Mg}^{2+}(\mathrm{Cmol} / \mathrm{kg})$ & 2.0 & 2.2 \\
$\mathrm{Bulk} \mathrm{density}\left(\mathrm{cm}^{3}\right)$ & 0.09 & 0.09 \\
Physical Properties of Soil $(\%)$ & 1.2 & 1.18 \\
Sand & 69.1 & \\
Silt & 15.5 & 67.6 \\
Clay & 15.4 & 17.0 \\
\hline
\end{tabular}

Table 2 shows the flow velocities, $\mathrm{v} \mathrm{m} / \mathrm{s}$, in the open channels dug as collectors of runoff water to the 12 graduated pits constructed for runoff collections for each of the plots of farm in the two depths of tillage. There were statistical differences between the flow velocities of the upper and lower parts of the collectors, this was not so only because of the slope of the channel which varied between $0.78 \mathrm{~m} / \mathrm{s}$ and $0.8 \mathrm{~m} / \mathrm{s}$ but also may be due to the nature of the soil.

However, as shown in Table 2, there was a lower mean flow velocity $(0.091 \pm 1.23 \mathrm{~m} / \mathrm{s})$ in the lower part of the channel than in the upper part's mean flow velocity $(0.155 \pm 0.70 \mathrm{~m} / \mathrm{s})$ of the channel. This was an upset as it deviated from normalcy, because the usual trend is that water movement and their velocities in the lower region of any channel are always higher than in the upper channel when conditions are the same. As recorded for hybrid varieties plots so also it was for the OPV plots. However, the highest flow velocity was obtained in the upper part $(0.156 \pm 10.18$ $\mathrm{m} / \mathrm{s}$ being the highest) as shown in Table 2. It is obvious that the computed flow velocities of runoff for the upper part was higher than that of flow velocity of runoff for the lower part $(0.093$ $\pm 7.34 \mathrm{~m} / \mathrm{s}$ ) and that the obtained standard deviation is higher in OPV than in hybrids despite almost 
the same essential soil factors the maize plants were subjected to for their growth. This shows wider range of mean flow velocities in OPV than in the hybrids plots.

The water percolation values in the lower parts of collectors were more in the $0-30 \mathrm{~cm}$ depth than 0-15 cm depth. Evidence of this could be ascertained from the recorded average infiltrometer values of $15.00 \pm 3.24 \mathrm{~mm} / \mathrm{h}$ and $16.50 \pm 2.40 \mathrm{~mm} / \mathrm{h}$ respectively in the upper part and the lower part which were recorded during three different rainfalls in the hybrid maize section. Also, water percolation values $15.10 \pm 4.20 \mathrm{~mm} / \mathrm{h}$ and $16.00 \pm 4.84 \mathrm{~mm} / \mathrm{h}$ respectively in the upper part and the lower part were recorded during three different rainfalls in the open pollinated maize section.

Table 2: Flow velocities of water in the collector to the pit at different depths of tillage in both hybrids and open pollinated sections

\begin{tabular}{llc} 
Description & \multicolumn{2}{l}{ Mean flow velocities, $\mathrm{v}, \mathrm{m} / \mathrm{s}$} \\
& Hybrids & OPV \\
& & \\
Upper part of channel & $0.155 \pm 0.70 \mathrm{a}$ & $0.156 \pm 10.18 \mathrm{a}$ \\
Lower part of channel & $0.091 \pm 1.23 \mathrm{~b}$ & $0.093 \pm 7.34 \mathrm{~b}$ \\
\hline
\end{tabular}

Mean values with the same letters along the same column are statistically different at $\mathrm{p} \leq 0.05$

Table 3 also shows the volumes of runoff water in the graduated dug pits of water for each of the plots of farm in the two tillage depths. The $0-15 \mathrm{~cm}$ depth accumulated more runoff water than the $0-30 \mathrm{~cm}$ depth of tillage.

Although, all the field treatments received the same amount of rainfall, different observations were recorded, there was a difference in the mean volume of water accumulated to the extent that there was $23.33 \%$ of volume of water accumulated in $0-15 \mathrm{~cm}$ depth of tillage field over that accumulated in 0-30 $\mathrm{cm}$ depth of tillage field in the maize hybrids plot. Contrastingly, there was a difference of $31.52 \%$ of $0-30 \mathrm{~cm}$ depth over $0-15 \mathrm{~cm}$ depth for mean volume of water accumulated in the OPV plot, Table 3 . This could only mean that the $0-30 \mathrm{~cm}$ depth of tillage in maize hybrids plots in the experiment retained more water than the $0-15 \mathrm{~cm}$ depth of tillage. But this result was in contrast when it comes to OPV plot. This was because, the lesser the accumulated run off in the pit, implying the higher the water percolated in that same field. Here $0-15 \mathrm{~cm}$ tillage depth retained more water than the $0-30 \mathrm{~cm}$ depth of tillage in both maize hybrids and OPV plots in contrast to 
what actually happened in maize hybrid section. Cumulatively, 0-30 cm depth of tillage retained more water with $11.86 \%$ more than $0-15 \mathrm{~cm},\left(44.60 \mathrm{~m}^{3}>39.87 \mathrm{~m}^{3}\right)$, Table 3 .

There were statistical differences between the mean values for volumes of runoff accumulated in the dug pit from the upper and lower parts of the channels, Table 2. Just as in the flow velocities where unexpected happened in the channel velocities, the $0-15 \mathrm{~cm}$ and $0-30 \mathrm{~cm}$ depths of tillage accumulated water were individually higher than those of others in different depths of tillage and they were statistically different, Table 3 . The percent difference and standard deviations were higher especially in the OPV.

Although, the depth of the channel changed from $\mathrm{d}=0.20 \mathrm{~m}$ to $\mathrm{d}=0.22 \mathrm{~m}$ from upper to lower part due to scouring of the soil particles that have taken place due to the runoff, this eventually influenced changes in the wetted perimeter and hydraulic radius for the waterways and consequently all these observations might have further influenced the velocities of the moving water, Table 2.

Table 3: Mean volumes of accumulated water in the pit at different depths of tillage and different maize varieties

\begin{tabular}{llll}
\hline Treatments & $\begin{array}{l}\text { Depths of } \\
\text { tillage, } \mathrm{cm}\end{array}$ & $\begin{array}{l}\text { Mean volume, } \\
\mathrm{m}^{3} \text { of runoff } \\
\text { water collected }\end{array}$ & $\begin{array}{l}\text { Cumulative mean volume, } \\
\mathrm{m}^{3} \text { of runoff water collected } \\
\text { per depth of tillage }\end{array}$ \\
\hline Maize hybrids & $0-15$ & $15.54 \pm 5.23 \mathrm{a}$ & \\
& $0-30$ & $12.60 \pm 3.96 \mathrm{~b}$ & \\
Open pollinated & $0-15$ & $24.33 \pm 15.31 \mathrm{~b}$ & \\
maize & $0-30$ & $32.00 \pm 14.42 \mathrm{a}$ & \\
& $0-15$ & & $15.54+24.33=39.87$ \\
& $0-30$ & & $12.60+32.00=44.60$ \\
\hline
\end{tabular}

Mean values with the same letters along the same column for each of the depth of tillage are statistically different at $\mathrm{p} \leq 0.05$

There were more percolations of water in 0-30 $\mathrm{cm}$ depth but these retained water could have drained beyond the rhizopheres of the maize fibrous roots where the water could be made used of as needed for the absorption of nutrients needed for photosynthesis. This could have led to discrepancies in the recorded yields as obtained in the end, Table 4. 
There were statistical differences between the mean values for yield in $\mathrm{tha}^{-1}$ in each of the hybrids and OPV fields, Table 4. These differences were both in $0-15 \mathrm{~cm}$ over $0-30 \mathrm{~cm}$ in both treatments, both fields and it was visibly pronounced in the hybrids with $500 \%$ more in $0-15 \mathrm{~cm}$ depth over 0-30 cm depth, although, it was only 34.78\% increase yield in 0-15 cm depth over 0-30 cm depth in the OPV field. The yield recorded for both the OPV and hybrids varieties were varying as depicted by their mean values. It is of note that the yield got in the experiment $\left(9.30 \pm 4.26\right.$ tha $\left.^{-1}\right)$ were lower than what was got by some farmers (Lamidi \& Afolabi, 2016; Lamidi, 2013) as 10-12 $\mathrm{t}$ ha $\mathrm{a}^{-1}$ yield have been reported.

Table 4: Yield of maize $\left(\mathrm{t} \mathrm{ha}^{-1}\right)$ at different depths of tillage

\begin{tabular}{lll}
\hline Treatments & Depths of tillage, $\mathrm{cm}$ & Cumulative yield, $\mathrm{t} \mathrm{ha}^{-1}$ \\
\hline Maize hybrids field & $0-15$ & $0.96 \pm 0.43^{\mathrm{a}}$ \\
& $0-30$ & $0.16 \pm 0.18^{\mathrm{b}}$ \\
& & \\
Open pollinated maize field & $0-15$ & $9.30 \pm 4.26^{\mathrm{a}}$ \\
& $0-30$ & $6.90 \pm 1.23^{\mathrm{b}}$
\end{tabular}

Mean values with the same letters along the same column for each of the depth of tillage are statistically different at $\mathrm{p} \leq 0.05$

\section{Discussion}

The significant difference revealed in the properties of the soil show that they are not completely capable of supporting maize's good production, whether hybrids or OPV. This could be said because of the level of the available $\mathrm{P}$ and $\mathrm{N}$ and organic carbon contents, Table 1 . But the proportion of silt and clay in both could allow water percolation in the sandy soils textural classification of the soil (Table 1).

The highest flow velocity of upper part could be because of the slopeness, $\mathrm{z}$ of the land which was $10 \%$, this is higher, and also because of the slope value, the more the slopeness, the more the flow velocity will be and the depth of flow may change; all these may lead to scouring of the soil along the waterway (Roberto et al., 2013; Telles et al., 2011).

From Table 2, the lower mean value of the flow velocity in the lower part of the collectors compare to upper part mean values reveals that flow velocity of a channel for the collectors could be as a 
result of different depths of tillage. This may be so since soil factors could have been constant as they are almost the same in all the treatments, Table 1. The channels have collectors' channel depth of $0.22 \mathrm{~m}$, this was deeper than $0.20 \mathrm{~m}$, which could have further help in accelerating the water movement than in the upper part of the channel of $0.20 \mathrm{~m}$. Again, this may shows that, even though the depth of channel was a little bit deeper $(0.22>0.20 \mathrm{~cm})$, these higher standard deviations (Table 2) imply wider range of flow velocities because of the depth $0.22 \mathrm{~cm}$ which was not maintained as runoff continued to scourge the soil capable of making the depth increases in the lower part of the channel than in the upper part. This also could have been possible because of the tilled depths' variance in the experiment.

Although the land topography was relatively stable, however it would not continue like that for long because of the watershed size. Moreover, just as slope increases the flow velocities, the maize' leaves planted could have interrupted rain splashes and thereby reduce their impacts on the soil, leading to low velocities of flow, $0.156 \pm 10.18 \mathrm{~m} / \mathrm{s}$ being the highest recorded, Table 2 . The slope, the rain splashes and the probable rain intensities which led to high infiltrometer values of $15.00 \pm 0.24 \mathrm{~mm} / \mathrm{h}$ and $16.50 \pm 0.40 \mathrm{~mm} / \mathrm{h}$ might have further led to more soil scourging resulting in deeper channel than the initial and eventually led to more flow velocities of runoff.

The statistical differences between the flow velocities of the upper and lower parts of the collectors in the channel, could be because of the slope of the channel which varied, $\mathrm{z}=0.78$ and 0.8 , or because of the tendency of the water to run faster in the lower part of the channel than the upper part, but could also be due to different depths of tillage and the different portions in the watershed geographic area which they were subjected to. Although randomized, one depth of tillage differentials could as well led to the other one and then some properties like percolations, water movements in the channel could have been affected, this was once noted by Telles et al. (2011).

Again, the statistical differences between the mean values for volumes of runoff accumulated in the dug pit from upper and lower parts of the channels could be because of the slope of the channel, it could also be because of water percolations and its erodability and different depths of tillage employed in the experiment. Just as in the flow velocities where unexpected happened in the channel velocities, the $0-15 \mathrm{~cm}$ and $0-30 \mathrm{~cm}$ depths of tillage accumulated water were individually 
Rwanda Journal of Engineering, Science, Technology and Environment, Volume 4, Issue 1, June 2021

eISSN: 2617-233X | print ISSN: 2617-2321

higher than that of other recorded flow velocities. It could be because the scouring of the soil that gave rise to deeper channels than what they were initially. Further scouring of the soil maybe surmised to have occurred because of the nature of the soil in the field.

Although, both fields received the same amount of rainfall, different observations were recorded.

The percolation of water that was more in the lower part of the collector could be supplementary reason to the different depths of tillage for the reduced velocity of flow of runoff in the lower part of the collector. Evidence of rate of water percolation was more in the lower parts of the constructed waterways, of both fields, this could be ascribed to the fact that soils in these parts were penetrable than those in the upper part, this may be so since the soil throughout the fields were all soil loam. Besides, velocity of water movement in the lower part was higher than in the upper part, Table 2, then, the nature of the soil in the area may be the reason why more water have penetrated in the lower part than in the upper part in the channel.

Another reason was that the average values in all cases (velocities of flow and infiltrometer values) were calculated for both the depths in each of the treatments, the $0-30 \mathrm{~cm}$ depth of tillage had higher water penetration values than the $0-15 \mathrm{~cm}$ depth of tillage in both the lower and upper parts of the waterways, Clausen et al., (1996) also observed the same about water penetrating the soils in varying strengths in nearly almost the same fields. Thus, depth of tillage have effect on the water percolation in the field and it was more for $0-30 \mathrm{~cm}$ than $0-15 \mathrm{~cm}$ depths. This could be so because water movement due to gravitational pull in the $0-30 \mathrm{~cm}$ depth of tillage couldn't have any impenetrable pan so close to the top soil as to impede water movement whereas, $0-15 \mathrm{~cm}$ depth of tillage could have, thus, the differences in the water percolation rate values. Both fields allowed percolation of some water in the collectors and allow runoff of some, this happened to a difference of an appreciable value of $70.33 \%$ for hybrids and $67.74 \%$ for OPV values for $0-15 \mathrm{~cm}$ depth over $0-30 \mathrm{~cm}$ depth. It could only mean that the flow velocities in $0-15 \mathrm{~cm}$ depth of tillage in hybrids plots in the experiment flow in such a manner that it helps to retain more water than the $0-30 \mathrm{~cm}$ depth of tillage, Table 2 .

There was about $500 \%$ increase yield of maize in $0-15 \mathrm{~cm}$ depth of tillage over $0-30 \mathrm{~cm}$ depth of tillage, this was too high. Many factors could have led to this, tillage practices employed, depth of 
tillage as the experiment was designed, rainfall intensities and there might have been some other factors like the breeds/hybrids. The factors like nutrients in the soil and nature of soil could also have contributed to this as they were significant as depicted in Table 1 as analysed for both fields. Contrastingly, the reverse is the case in the open pollinated maize field, volume of water in the watershed was higher in the $0-30 \mathrm{~cm}$ plot, implying its water retention is lower than the $0-15 \mathrm{~cm}$ depth of tillage. Since the fields are side by side, with the same rainfall and same other conditions, it is obvious that another factor could have been responsible, like soil factors (Table 1). There are differences in the physical properties of the soil (even though they are side by side), as shown in Table 1.

OPV shows higher yields at both depths of tillage than the hybrids. This could not be explained as the hybrids should have yielded highly than OPV since its genetical variability have been changed and tilted toward high yield by the breeding processes it went through. Nevertheless, the result could have been due to genetical variability and it could also be due to watershed and water retaining capacities of different plots where they were planted and also the water mean flow velocity values' differentials as in Table 2 . The $0-15 \mathrm{~cm}$ depth of tillage was with highest yield, this could only be adduced to the fibrous nature of the maize plant where their roots may not reach to deeper than $15 \mathrm{~cm}$. Nutrients' accessibility of the roots around the $0-15 \mathrm{~cm}$ depth could be said to be better for maize than the $15-30 \mathrm{~cm}$ depth. Also, factors that may also be responsible could be soil factors especially lower organic carbon, Table 1, low available $\mathrm{N}$ and $\mathrm{P}$ also could be contributing factor. This could be because both hybrids and OPV were grown under the same conditions, same weather and they were side by side to each other's fields.

The statistical differences between the mean values for yield in $\mathrm{t} \mathrm{ha}^{-1}$ in each of the hybrids and OPV fields resulted into big discrepancy, this may be due to many factors like slope of the channel (z) which varied between 0.78 and 0.80 that might have affected water percolations and watershed variations. It could have been also affected by the nutrients' erodability and possibly genetical variations.

For the fact that maize was used as the field crop and the yield was more in the $0-15 \mathrm{~cm}$ depth of tillage than the $0-30 \mathrm{~cm}$ of tillage depth could only mean that its fibrous roots in the rhizosphere 
Rwanda Journal of Engineering, Science, Technology and Environment, Volume 4, Issue 1, June 2021

eISSN: 2617-233X | print ISSN: 2617-2321

were comfortable and nutrients' friendly. If other crops that can extend their roots beyond 0-15 cm depth were used, results could possibly have been different or couldn't have been different. That is, if cassava or yam tubers were planted, results could possibly have been different.

\section{Conclusion}

The 0-30 cm tillage depth retained more water than the $0-15 \mathrm{~cm}$ depth of tillage, thus the volume of water retained by $0-15 \mathrm{~cm}$ was higher than the volume of the water retained by0-30 $\mathrm{cm}$ depth of tillage. In effect, there was an increase yield in maize planted in 0-15 cm depth over 0-30 cm depth to almost $500 \%$ increment. Being a fibrous root plant, $0-15 \mathrm{~cm}$ depth of tillage was good for maize than 0-30 cm depth of tillage for hybrids and open pollinated maize varieties.

\section{References}

Anderson, J.A. \& D'Sinza, S. (2014). From adoption claims to understanding farmers and contexts: A literature review of Conservation Agriculture (CA) adoption among smallholder farmers in southern Africa. 2014. Agriculture, Ecosystems \& Environment 187, 1-94. DOI: 10.1016/J.AGEE.2013.08.008

Brady, N.C. \& Well, R. R. (2002). The Nature and Properties of Soils. (13ed, 2002). Prentice-Hall Inc. New Jersey, USA. 976. http://www.sciepub.com/reference/105098

Clausen, J.C., Jokela, W.E., Potter II, F.I., \& Williams. J.W. (1996). Paired Watershed Comparison of Tillage Effects on Runoff, Sediment, and Pesticide Losses. Journal of Environmental Quality, 25(5),1000-1007. doi.org/10.2134/jeq1996.00472425002500050011x

Ghaderi-far, F, Gherekhloo,J \& Alimagham, S. M. (2010). Influence of environmental factors on seed germination and seedling emergence of yellow sweet clover (Melilotus officinalis).

Planta Daninha 28(3), 463-469. https://doi.org/10.1590/S0100-83582010000300002

Kim, Y.S, Kim, T.J, Kim, Y.J, Lee, S.D, Park, S.U \& Kim, W.S. (2020). Development of a RealTime Tillage Depth Measurement System for Agricultural Tractors: Application to the effect and analysis of Tillage Depth on Draft Force during Plow Tillage. Sensors Basel, 20(3), 912 https://www.ncbi.nlm.nih.gov/pmc/articles/PMC7038978/

Lamidi W. A. \& Afolabi M. S. (2016). Influence of some environmental factors on maize productivity in Osun State, Nigeria. Ethiopian Journal of Environmental Studies and 
Rwanda Journal of Engineering, Science, Technology and Environment, Volume 4, Issue 1, June 2021

eISSN: 2617-233X | print ISSN: 2617-2321

Management, 9 (2), Supplementary 2, 1009-1021. doi.org/10.4314/ejesm.v9i2.7S http://www.ajol.info/index.php/ejesm/article/view/150117/139683.

Lamidi, W.A. (2014). Watershed management for controlling field erosion using some adopted developmental processes. International Journal of Ecological Science and Environmental Engineering, $\quad 1(2)$, 43-48. http://www.aascit.org/journal/archive2?journalId=904\&paperId=900

Lamidi W. A. (2013). Maize (Zea-Mays) performance at different cultivation systems. Journal of Biology, Agriculture and Healthcare. 3 (3), 172-182. http://www.iiste.org/Journals/index.php/JBAH/article/view/4763/4842

Molatudi R. L. \& Mariga I.K. (2009). The effect of Maize seed size and depth of planting on seedling emergence and seed vigor. Journal of Applied Sciences Research. 5(12), 22342237. http://eprints.icrisat.ac.in/451/1/J.Appl.Sci.Res.5_12_2234_2237_2009.pdf

Owen, H.A. (2006). Performance of a passive small-plot runoff collector under laboratory and field conditions. Retrospective thesis and Dissertation. https://lib.dr.iastate.edu/rtd/19102

Pagliari, P.H., Ranaivoson, A.Z. \& Strock, J.S. (2021). Options for statistical analysis of unreplicated paired design drainage experiments. Agricultural Water Management, 244: 10.1016/j.agwat.2020.106604;244,2021 (106604). doi.org/10.1016/j.agwat.2020.106604

Pittelkow C.M, Linquist, B.A, Mark E. Lundy M.E, Liang X, Groenigen K.J., Lee J. Gestel, N., Six J.,.Venterea, R.\& Kessel, C. (2015). When does no-till yield more? A global metaanalysis? Field Crops Research. 183, 156-168. https://doi.org/10.1016/j.fcr.2015.07.020

Roberto A.C, Michel C.M., Jose E.M.P., Fernando F.P \& Danilo C.F. (2013). Assessing rainfall erositivity indices through synthetic precipitation series and artificial neural networks. (Annals of the Brazilian Academy of Sciences) Anais da Academia Brasileira de Ciencias, 85 (4), 1523-1535. https://doi.org/10.1590/0001-3765201398012

Schwab, G.O, Frevert, R.K, Edminister, T.W. \& Barnes, K.K. (1981). Soil and Water Conservation Engineering. John Wiley and Sons Inc., New York, Third Edition

Telles T.S., Guimaraes M.F and Dechen S.C.F. (2011). The costs of soil erosion. Rev Bras Ci Solo 35, 287-298. https://doi.org/10.1590/S0100-06832011000200001

Uttah State University Extension (2018). What is Watershed? Water Quality Menu, additional resources. https://extension.usu.edu/impacts/ 
Rwanda Journal of Engineering, Science, Technology and Environment, Volume 4, Issue 1, June 2021

eISSN: 2617-233X | print ISSN: 2617-2321

Viennet, J. C., Jacquemot, P., Bernard, S. Guillou, L.C, Rigaud, B \& Delbes, L. (2019). The degradation of organic compounds impacts the crystallization of clay minerals and vice versa. Sci Rep 9, 20251 DOI: 10.7185/geochemlet.1931 